\title{
Investigating the effect of Sesame Ointment on Wound healing of Episiotomy
}

\author{
Research Article
}

\author{
Najmeh Amani Babadi ${ }^{1}$, Masoomeh Kheirkhah ${ }^{2 *}$ Faraz Mojab $^{3}$, Hamid Haghani $^{4}$ \\ 1. Student of Midwifery, Iran University of Medical Sciences, Tehran, Iran \\ 2. Assistant Professor, head of department of Midwifery, Iran University of Medical Sciences, Tehran, Iran. \\ 3. Professor, department of Pharmacognosy, Shahid Beheshti University of Medical Sciences, Tehran, Iran. \\ 4. Lectures, department of Biostatistics, Iran University of Medical Sciences, Tehran, Iran.
}

\begin{abstract}
Episiotomy is one of the most common midwifery interventions method for preventing injuries to the pelvic floor during the delivery process. Traditional medicine has a special place in improving the quality of postpartum care. Sesame is one of the herbs with anti-inflammatory, anti-bacterial and antioxidant activity. This study was evaluate the effect of sesame ointment on episiotomy healing. Methods: This randomized control clinical trial was performed on 104 eligible women. The samples were block randomly assigned to one of the groups Intervention and control. Samples were used sesame and placebo ointment for epizootics from 4 hours after delivery for ten days every 8 hours. Clinical evaluation of episiotomy ulcer was performed 4 hours, 7 and 10 days after delivery with using REEDA tool. SPSS software version 16 was used for data analysis. P value less than 0.05 was considered significant. Results: The average of wound healing rate was 7 days after episiotomy in the intervention group $0.09 \pm 0.29$ and in the control group was $0.73 \pm 0.44$. Independent t-test showed that the two groups had a significant difference $(\mathrm{p}<0.001)$. Healing of the wound 10 days after episiotomy showed that the mean scores in the control group $(0.4 \pm 0.49)$ and in the intervention group $(0.02 \pm 0.13)$, healing in the intervention group significantly decreased from the control group $(\mathrm{p}<0.001)$. Conclusion: Sesame ointment can be used as a pain relief and accelerator for episiotomy healing.
\end{abstract}

Keywords: Episiotomy, Sesame ointment, wound healing, Pain intensity.

\section{Introduction}

Consumption of sesame seed oil and its topically or orally improves the wound (18-20). The World Food and Drug Administration has not approved the use of herbal medicines for sesame and its use has not been mentioned. A study to investigate the effects of various ozone-containing vegetable oils on healing of wounds has shown that sunflower oil is more effective in treating wounds (21). External use of sesame oil has been effective in reducing the severity of pain caused by bodily injuries and also reducing the use of nonsteroidal anti-inflammatory drugs and has been considered as a therapeutic approach to reducing the pain intensity of affected patients (22). Sesame oil have been effective in preventing sterilization and itching caused by primipara women (23).

No study has been done on the effect of sesame on episiotomy wound healing. The researcher, as a midwife who is responsible for producing knowledge and performing applied research in the field of recognition and development of traditional Iranian

*Corresponding Author:

Masoomeh Kheirkhah

Assistant Professor,

Head of Department of Midwifery,

Iran University of Medical Sciences,

Tehran, Iran.

Email: kheirkhah.m@iums.ac.ir medicine in promoting maternal health, decided to conduct a study to investigate the effect of sesame ointment on episiotomy ulcer healing. Positive results and confirmation of its effectiveness can be used to recommend the use of sesame ointment for improving episiotomy wound healing and promoting women's health for healthcare professionals, midwives, and gynecologists.

\section{Method}

The present study was a randomized, Triple Blind Clinical Trial with an intervention group and a placebo group. The type of intervention was considered as an independent variable and episiotomy ulcer healing as a dependent variable.

\section{Results}

Individuals in two groups did not have a significant difference in terms of personal characteristics such as age, level of education, economic status, occupation, episiotomy length, duration of first, second and third stages of labor, number of sutures, head circumference, BMI. Two groups Consideration of postpartum factors such as the highest status of the mother during lactation and the time of onset of daily activity after delivery and the use of sedative drugs were significant (Table -1) 


\begin{tabular}{|l|c|c|c|}
\hline \multicolumn{4}{|c|}{ Table 1. Comparison of some of the delivery data of the research samples in } \\
two groups of drugs and placebo
\end{tabular}

\begin{tabular}{|l|c|c|c|}
\hline \multicolumn{4}{|c|}{ Table 2 - Scale of healing scores in two groups and its significant test } \\
\hline Wound healing & Before intervention & After 7 days & After 10 days \\
\hline Sesame ointment group & $1.86 \pm 0.48$ & $0.09 \pm 0.29$ & $0.02 \pm 0.13$ \\
\hline Placebo ointment group & $1.86 \pm 0.39$ & $0.73 \pm 0.44$ & $0.4 \pm 0.49$ \\
\hline \multirow{3}{*}{ Test results } & $\mathrm{t}=0.029$ & $\mathrm{t}=8.614$ & $\mathrm{t}=5.448$ \\
& $\mathrm{df}=103$ & $\mathrm{df}=103$ & $\mathrm{df}=103$ \\
& $\mathrm{p}=0.977$ & $\mathrm{P}<0.001$ & $\mathrm{P}<0.001$ \\
\hline
\end{tabular}

However, there was no significant difference between the 7th and the 10th day after the intervention. In the control group, the results showed that the wound healing before the intervention was 7 days and 10 days after episiotomy was significant. 7 days later and 10 days later Significant statistical differences were observed in episiotomy in the wound healing score.Ismaili et al. (2012) A double-blind clinical trial with the aim of determining the effect of turmeric solution on episiotomy ulcer healing in two groups of intervention (turmeric solution) and control (iodine) for ten days. Wound healing was assessed for 24 to 48 hours as well as 10 days after delivery. The findings indicated that the mean and standard deviation of Reida score in the turmericle consumer group 24 hours after episiotomy was significantly lower than that of the control group (27).

Turmeric raw extract like sesame, chamomile and evergreen flowers have several properties, including anti-inflammatory, anti-bacterial, antiviral properties and have wound healing function. Azari et al. (2014) conducted a tri-blinding clinical trial entitled "The study of the effect of chamomile cream on the improvement of episiotomy ulcer in primiparous women."Evaluation was performed on the first, seventh, tenth and fourteenth days after delivery. The results showed that in the first day of birth, the two groups did not differ in terms of RIDA score, but the two groups had significant differences in terms of wound healing in the seventh, tenth and fourteenth days. (28).The results of this study were compared with the results of this study in a manner consistent with the results of study by Jahdi et al. (2012), which investigated the effect of Calendula officinalis ointment on episiotomy healing in nulliparous women. Use of Calendula officinalis ointment increases episiotomy wound healing rate significantly and has healing properties, antiinflammatory and antimicrobial properties (29).Mohammad AliEe et al. (1393) In a study, we investigated the effect of gelatin ointment on episiotomy ulcer healing in primiparous women on 84 primiparous women referred to Baharlo hospital in Tehran. The results showed that the mean and standard deviation of
Rida score on the 5th day after delivery in the intervention group was significantly lower than the placebo group, which is consistent with the results of the present study (30).

Among the limitations of this study were the impossibility of complete control of nutrition, the level of individual health and the physical activity of mothers after delivery, all necessary post-partum training was provided.In addition, the difference in labor factor from the onset of the sampling to the end of the study was the other limitations of the study, which the research team controlled partly by monitoring the mode of delivery and randomization.

\section{Conclusion}

Sesame oil has anti-inflammatory and microbial properties and can be used to accelerate episiotomy wound healing. Given the increasing tendency of people to use herbal medicines in recent years, Sesame ointment can be used. As a factor increasing the speed of healing and episiotomy recommends postpartum primiparous women.

\section{References}

1. Bharati A, Reddy D, Dharma K,SHarath GKote GS., A prospective randomized comparative study of vicryl rapide versus chromic catgut for episiotomy repair. J Clin Diagn Res 2013; 7(2):326-330.

2. Ho, J.J., Pattanittum, P., Japaraj, R.P., Turner,T., Swadpanich, U. and Caroline, A. (2010) Influence of training in the use and generation of evidence on episiotomy practice and perineal trauma. International Journal Obstetric Gynecology, 111(1), pp. 13-18.

3. AL-Ghammari, K., AL-Riyami, Z., AL-Moqbali, M., AL-Marjabi, F., AL-Mahrouqi, B. and AL-Khatri, A. (2016) Predictors of routine episiotomy in primigravida women in Oman. Appl Nurse Res, 29, pp. 131-135.

4. Justin, R.L. and Dana, R.G. (2010) Changes in Episiotomy Practice: Evidence-based Medicine in Action. Expert Rev of Obstetric Gynecology, 5(3), pp. 301-309. 
5. Khani,S., Zare,K.,Ramadan Nejad,E. (2011 ( Frequency of episiotomy and its related factors. Journal of Nursing, 24 (74).

6. Khajevi, Sh,K., Dewati,A., Zayeri,F. (2009) Complications and related factors in episiotomy in nulliparous women referred to hospitals in Tehran. Quarterly Journal of Urmia Nursing and Midwifery Faculty, 7 (4), p. 217-223.

7. Albers, L.L. and Borders, N. (2007) Minimizing genital tract trauma and related pain following spontaneous vaginal birth. J Midwifery Wom Heal, 52(3), pp. 246-253.

8. Boyle, M. (2006) .Wound healing in midwifery. United Kingdom: Radcliffe Publishing: Oxon.

9. Ricci, S. and Kyle, T. (2009) Maternity and Pediatric Nursing. Wolters Kluwer Health: Lippincott Williams \& Wilkins, pp. 448.

10. Hicks, T.L., Goodall, S.F., Quattrone, E.M. and Lydon-Rochelle, M.T. (2004) postpartum sexual functioning and method of delivery: Summary of the evidence. J Mid-Wom Heal, 49(5), pp. 430-436.

11. Abdool, Z., Thakar, R. and Sultan, A.H. (2009) postpartum female sexual function. Eur J Obstet Gynaecol Reprod Biol, 145(2), pp. 133-137.

12. Fernando, R., Sultan, A.H., Kettle, C., Thakar, R. and Radley, S. (2006) Methods of repair for obstetric anal sphincter injury. Cochrane Database Syst Rev, 3.

13. Malekpour, P. and Sehatie, F. (2009) .The effect of turmeric solution on pain intensity on episiotomy in primiparous women. J Nurse Midwifery Faculty Tehran University Medical Sciences.

14. Habibian Dehkordi, S., Karimi, A., Tavakoli, N., Kabouteri, J. (2013 (Effects of Alcoholic Extract of Brassicae Orchid on the Healing of Bald Wounds in Rabbits. Iranian Journal of Veterinary Clinical Sciences, 7 (2).

15. Huang, S.T. and Chen, A.P. (2008) Traditional Chinese medicine and infertility. Current Opinion Obstet Gynecol, 20, pp. 211-215.

16. Mossalai,P, M., Eghtesadi,Sh., Kaseb,F. and Afkhami,A, M.andHosseini,F.(2009) ,Effect of sesame oil on lipid profile and blood sugar of type 2 diabetic patients referred to Yazd Diabetes Research health Center, Journal of Shahid Sadoughi University of Medical Sciences Yazd, 16 (2),pp.15-23.

17. Ebrahimi,F,H.(2006), The Effect of calcium hydroxide and sesame oil ointment on debridement time non-surgical in adult male rats with 3 degree burn wound, Arak Medical University Journal , (4),pp.1-33.

18. Koatod,K., Mohammed,A. (2008), Wound healing activity of sesamum indicium $L$ seed and oil in rats, .Indian Journal of Experimental Biology,46,pp.777782.

19. Valacchi,G., Lim, Y., Belmonte,G.and Miracco,C. and Zanardi,I. and Bocci,V.(2011) ,Ozonated sesame oil enhances cutaneous wound healing in SKH1 mice, Wound Repair Regen,19,pp.107-115.
20. Valacchi G, Zanardi,I., Lim, Y., Belmonte,G. and Miracco,C. and Sticozzi,C.(2013). Ozonated oils as functional dermatological matrices: effects on the wound healing process using SKH1 mice, Int J Pharm, 458, pp.65-73.

21. Mohammad Tawfiq,A.,Hussein,A.,Khosrow,H., Ayazi,M,A., Nemati.H.B.,Safdari,F. (2014, (The effect of ointment containing sesame oil, honey and camphor (kimia) on compressive wounds in diabetic patients, Journal of Medical Research, Shahid Beheshti University of Medical Sciences, Shahid Beheshti University of Medical Sciences, Vol. 38, No. 3 , Pp.131-138

22. Bigdeli Shamloo, M,B., Debirian,A.,Bakhtiari,A., Mojab,F.,.Alavi,M,H. (2014 ,(The Effect of Topical Application of Sesame Oil on the Severity of Pain and Nonsteroidal Anti-Inflammatory Drug Use in End-Ended Damaged Patients, Second National Conference on Medicinal Plants and Sustainable Agriculture, Shahrivar.

23. Malekoti,J.,Farshbaf,F,A, Kamrani,A.(2015), Effect of Sesame Oil and Almond Sweet on Streia and Prevention of Itching in parmipar wemon: A Randomized Controlled Trial, Iranian Journal of Obstetrics and Gynecology and Infertility, Volume 18, No. 169 , p. 1-11.

24. Vakilian K, Atarha M, Bekhradi R, Qiblah F, Hatami Z, Seraj A. Effect of lavender essential oil in wound care episiotomy after delivery. J Med Sci Shahrekord 2008; 10(3):63-9. (Persian).

25. Yashashri.P.(2014), Effectiveness of moist heat and dry heat application on healing of episiotomy wound. Asian Journal of Multidisciplinary Studies, 2 (7), pp.225-236.

26. Venkadalakshmi V, Venkatesan L, Perdita HM. Effect of Infrared Therapy on Episiotomy Pain and Wound Healing in Postnatal Mothers. The Nursing Journal ofIndia. 2010; 101(9): 212-214.

27. Esmaeli Vardanjani, S., Sehati Shafai, F., Mohebi, P., Deyhimi, M., Delazar, A., Ghojazade, M. \& Malepour, P. 2012. Wound healing benefits of curcumin for perineal repair after episiotomy: results of an Iranian randomized controlled trial. LIFE SCIENCE JOURNAL-ACTA ZHENGZHOU UNIVERSITY OVERSEAS EDITION, 9, 5536-5541

28. Azhari, S., Aradmehr, M., Rakhshande, H., Tara, F. \& Shakeri, T. 2014. Evaluation of the effect of chamomile cream on episiotomy ulcer in nulliparous women. Tthe iranian journal of obstetrics gynecology and infertility, 17, 16-26.

29. Jahdie, F., Eghdampour, F., Haseleie, A., Kheirkhah, M., Haghani, H. \& AbasiI, Z. 2012. The effect of Calendula ointment in wound healing of episiotomy among primiparous women admitted in Lolagar hospital of Tehran, 2010. JN Khorasan Univ Med Sc, 5, 117-23.

30. Mirmohamadali, M. 2014. Evaluation of the effect of ointment on the severity of perineal pain and episiotomy healing. Master's degree, Faculty of Nursing and Midwifery, Tehran University of Medical Sciences. 